\title{
OPTIMALISASI MASALAH TRANSSHIPMENT DENGAN MENGGUNAKAN VOGEL APPROXIMATION METHOD PADA DISTRIBUSI PLASTIK DI PT. SENTOSA PLASTIK MEDAN
}

\author{
Swandi Simanjorang, Faiz Ahyaningsih \\ FMIPA Universitas Negeri Medan, Medan, Indonesia \\ suesinagamanjorang@gmail.com
}

\begin{abstract}
Abstrak
Penelitian ini mengkaji hasil model transshipment dari proses pendistribusian barang di PT Sentosa Plastik Medan dengan menggunakan program WinQSB. Selain itu, model transshipment proses pendistribusian barang oleh perusahaan dibandingkan dengan model transshipment yang dihasilkan oleh program Solver.

Metode yang digunakan dalam penelitian ini adalah metode dokumentasi, metode wawancara, dan studi pustaka. Data dalam penelitian ini diperoleh dari perusahaan. Adapun uraian dari metode-metode transshipment adalah sebagai berikut: (1) Metode untuk menyusun tabel awal antara lain Metode Sudut Barat Laut atau North West Corner Method (NWC), Metode Biaya Terkecil atau Least Cost Method, Vogell's Aproximation Method atau VAM. (2) Model pegujian optimalitas algoritma transportasi antara lain Stepping Stone Method; dan Modified Distribution Method atau MODI. Berdasarkan hasil penelitian diperoleh bahwa selisih biaya pendistribusian untuk seluruh produk kain mori dengan menggunakan program WinQSB adalah sebesar Rp. 22.561.250,- lebih kecil dibandingkan hasil perhitungan perusahaan sebesar Rp.35.488.750,- Ini berarti terdapat selisih antara biaya pendistribusian yang menggunakan program WinQSB dengan biaya pendistribusian yang dilakukan oleh perusahaan yaitu sebesar $R p$ 12.927.500,-. Jadi biaya pendistribusian masih dapat diminimalkan sebesar 36,4\%. Akan tetapi, sebelum melakukan tindakan lanjutan. Perusahaan juga perlu mempertimbangkan mengenai aspek dilapangan untuk meminimalkan biaya pendistribusian yang ada
\end{abstract}

Kata Kunci: Biaya Pendistribusian, Optimalisasi, WinQSB, dan Transshipment, Vogel Approximation Method (VAM)

\begin{abstract}
This study examines the results of the model transshipment of goods distribution process in PT Sentosa Plastic Medan using WinQSB program. In addition, the process of
\end{abstract}


distributing goods transshipment models by the company compared to the transshipment models produced by the Solver program. The method used in this research is the method of documentation, interviews, and literature. Data in this study were obtained from the company. The description of the methods of transshipment is as follows: (1) A method for preparing the initial table among other methods Northwest Angle or North West Corner Method (NWC), or Least Least Cost Method Cost Method, Vogell's aproximation Method or VAM. (2) Model test of optimality transport algorithms include Stepping Stone Method; and Modified Distribution Method or MODI. The research showed that the difference in the cost of distribution for all products cloth using WinQSB program is Rp. 22.56125 , - lower than the calculation results of the company for Rp.35.488.750, This means that there is a difference between the cost of distribution that uses WinQSB program at a cost of distribution conducted by the company in the amount of $\mathbf{R p}$. 12.9275 -. So the cost of distribution can still be minimized by $36.4 \%$. However, before making any further action. Companies also need to consider the aspect of the field to minimize the cost of existing distribution. Keywords: Distribution Costs, Optimizing, WinQSB, and Transshipment, Vogel Approximation Method (VAM)

\section{Pendahuluan}

\subsection{Latar Belakang}

Matematika sebagai dasar dan sarana bagi ilmu-ilmu lain untuk memunculkan berbagai aplikasi dari matematika dalam persoalan kehidupan sehari-hari. Salah satu penerapan matematika yang digunakan untuk menyederhanakan masalah ke dalam bentuk matematika adalah riset operasi. Riset operasi (RO) adalah teknik pemecahan masalah dalam pengambilan keputusan dengan memanfaatkan pengetahuan ilmiah melalui usaha kelompok antar disiplin yang bertujuan untuk menentukan penggunaan terbaik sumber daya yang terbatas $[.1,2,3]$

Metode riset operasi yang banyak digunakan secara luas dalam pengambilan keputusan dan diketahui dengan baik adalah program linear. Program linear yang diterjemahkan dari linear programing adalah suatu cara untuk menyelesaikan persoalan pengalokasian sumber-sumber yang terbatas di antara beberapa aktifitas yang bersaing, dengan cara terbaik yang mungkin dilakukan untuk memperoleh hasil yang optimum [4]. Sesuai dengan namanya model program linear, maka seluruh fungsi yang ada pada model ini merupakan fungsi linear, baik dalam bentuk persamaan maupun ketidaksamaan pada variabel-variabel keputusannya. Secara umum, fungsi pada model ini ada dua macam 
yaitu fungsi tujuan dan fungsi pembatas. Fungsi tujuan dimaksudkan untuk menentukan nilai optimum dari fungsi tersebut. Fungsi pembatas diperlukan dengan adanya keterbatasan sumber daya yang ada.

Program linear merupakan salah satu metode yang banyak digunakan di bidang industri, transportasi, perdagangan, perkebunan, kesehatan, teknik. Dalam bidangbidang usaha biasa, tujuannya berupa memaksimumkan profit atau meminimumkan ongkos yang harus dikeluarkan. Akan tetapi, dalam bidang-bidang lain yang sifatnya tidak mencari keuntungan (non-profit), tujuannya dapat berupa pemberian kualitas pelayanan kepada para konsumen. Pada bidang usaha yang bersifat profit, memperoleh keuntungan merupakan bagian dari tujuan yang hendak dicapai Meningkatnya kompleksitas dan spesialisasi dalam suatu perusahaan seperti ini membawa dampak pada makin sulitnya melakukan alokasi sumber-sumber daya yang dimiliki pada berbagai kegiatan secara efektif bagi perusahaan secara keseluruhan. Bagaimana cara memecahkan masalah alokasi sumber daya yang efektif ini, serta adanya kebutuhan untuk mencari cara yang lebih baik untuk memecahkan suatu masalah yang muncul dalam perusahaan telah mendorong timbulnya riset operasi (Operation Research) [5].

Metode distribusi yang terbaik pun tidak dapat dipastikan karena ada kemungkinan pengiriman lebih lanjut (transshipment) di mana kiriman-kiriman akan melalui titik-titik transit. Adapun masalah transshipment itu sendiri adalah masalah transportasi yang memungkinkan dilakukannya pengiriman barang dengan cara tidak langsung, dimana barang dari suatu sumber dapat berada pada sumber lain sebelum mencapai tujuan akhir [4]. PT.Sentosa Plastik Medan adalah perseroan terbatas yang memfokuskan pada produksi biji plastik dan polybag dari plastik bekas. Untuk mendistribusikan produk-produknya kepada konsumen, PT.Sentosa Plastik Medan menggunakan sistem pengiriman langsung dan tidak langsung PT.Sentosa Plastik Medan mengirimkan produk-produknya ke distributor ataupun agen-agen yang tersebar diberbagai kota dengan tujuan untuk mempercepat proses pendistribusian. Distributor ataupun agen-agen yang terletak di berbagai kota merupakan titik-titik transit produkproduk sebelum sampai pada tempat tujuan. Kemungkinan-kemungkinan pengiriman tidak langsung dapat diteliti sebelumnya untuk menentukan rute yang paling murah dari sejumlah sumber kesejumlah tujuan, sebab hal ini merupakan pekerjaan yang rumit dan memakan waktu jika titik-titik transit ini banyak.

Pada awalnya untuk menghitung biaya serta jarak paling minimum dilakukan perhitungan secara manual, namun seiring berjalannya waktu, maka perhitungan manual pun ditinggalkan, karena dirasa kurang efektif dan membutuhkan waktu yang lama. 
Pertimbangan efisiensi waktu dalam perusahaan sangat diperhatikan. Dengan demikian diperlukan adanya suatu alat, teknik maupun metode yang praktis, efektif dan efisien untuk memecahkan masalah tersebut. Oleh karena itu, untuk mempermudah penyelesaian dapat dilakukan dengan bantuan komputer. Untuk penyelesaian masalah ini telah tersedia beberapa program khusus, antara lain Lindo, Lingo, Solver dan WinQSB. WinQSB merupakan software yang mengandung algoritma problem solving untuk riset operasi (operational research) dan ilmu manajemen $[6,7,8,9]]$.

\subsection{Batasan Masalah}

1. Barang yang dikirim adalah produk plastik jenis polybag dengan berbagai ukuran (sejenis)

2. Daerah pengiriman barang adalah konsumen yang berada di Sumatera dengan pabrik sebagi titik sumber dan distributor/agen sebagai titik transit dan jalur yang dilewati adalah rute normal.

3. Plastik tidak mengalami kerusakan selama pendistribusian

4. Biaya penyimpanan diasumsikan tidak ada

5. Biaya pengiriman barang dari suatu gudang ke gudang lain dihitung untuk tiap unit barang $(\mathrm{kg})$

\section{Metode Penelitian.}

Penelitian ini akan dilaksanakan di .PT.Sentosa Plastik Medan selama kurang lebih satu bulan. Jenis penelitian yang diigunakan dalam penelitian ini adalah penelitiaan terapan (Applied Research) yaitu penelitian yang kegunaannya diarahkan dalam rangka memecahkan masalah-masalah praktis.

\subsection{Langkah-langkah Penelitian}

1. Survey Penelitian

Untuk mendapatkan gambaran tentang perusahaan serta pengamatan langsung pada obyek yang diteliti.

2. Studi Literatur

Untuk mendukung penelitian yang akan dilaksanakan sebagai pedoman dalam menganalisa dan mencari solusi dari permasalahan yang terjadi.

3. Penelitian Langsung

Dimana cara yang digunakan adalah observasi dan interview.

4. Mengumpulkan Data 
Data yang dikumpulkan adalah alamat setiap agen, jarak jalan, biaya transportasi, data permintaan dan penawaran pada tahun 2013

5. Membuat model transshipment

Setelah data dikumpulkan, maka data dibuat dalam bentuk model transshipment dan mengubahnya dalam bentuk transportasi

6. Membuat tabel distribusi awal

Dari data yang diperoleh, kemudian dibuat tabel distribusi plastik dariPT.SENTOSA PLASTIK MEDAN. Pembuatan tabelel distribusi plastik dilakukan untuk mempermudah perhitungan.

7. Membuat tabel pengujian optimal

Tujuan dari pengujian tabel awal anums untuk mengetahui apakah masih ada alternatif alokasi distribusi yang akan membawa beban biaya distribusi total menurut alokasi distribusi tabel awal

8. Mengolah data

Menghitung biaya ooptimal dengan Vogel Approximation Method (VAM). Untuk menghitung biaya optimal ini dibantu dengan mengunakan software WinQSB. Setelah data dimasukkan, pilih metode VAM untuk menghitung biaya optimal dari dari pendistribusian PT.SENTOSA PLASTIK MEDAN

\section{Hasil \& Pembahasan}

\subsection{Pengumpulan Data}

Dalam menyelesaikan persoalan pendistribusian bijih plastik dan polybag dengan menggunakan metode transshipment, data-data yang diperlukan adalah data banyaknya plastik dan polybag yang tersedia, banyaknya permintaan yang dibutuhkan setiap kota, dan biaya distribusi pada bulan Mei. Data tersebut diperoleh dari PT. Sentosa Plastik Medan yang dapat dilihat pada tabel dibawah ini : 
Tabel 1 Data Permintaan Plastik Bulan Mei 2015

\begin{tabular}{|l|c|c|c|c|c|c|c|c|c|}
\hline $\begin{array}{l}\text { Tujuan } \\
\text { Produk }\end{array}$ & Mdn & Ach & Duri & P.bru & Pdg & Pntk & Lpg & Jmb & Ttl \\
\hline $\begin{array}{l}\text { Bijih } \\
\text { Plastik }\end{array}$ & 3950 & 2800 & 2000 & 5150 & 1800 & 3200 & 2000 & 3100 & 24000 \\
\hline Polybag & 4200 & 1900 & 1400 & 4200 & 1650 & 2750 & 1800 & 2100 & 20000 \\
\hline Total & 8150 & 4700 & 3400 & 9350 & 3450 & 5950 & 3800 & 5200 & 44000 \\
\hline
\end{tabular}

*Kuantitas produk per satuan $\mathrm{kg}$

Sumber: PT.Sentosa Plastik Medan

Tabel 1 menunjukkan banyaknya permintaan Plastik di kota Medan, Aceh Tengah, Duri, Pekan Baru, Padang, Pontianak, Lampung dan Jambi. Permintaan plastik di Medan sebanyak 8150 kg, Aceh Tengah 4700 kg, Duri 3400 kg, Pekan Baru 5950 kg, Padang 3450 kg, Pontianak 5950 kg, Lampung $3800 \mathrm{~kg}$, Jambi $5200 \mathrm{~kg}$, total permintaan selama sebulan dari kedelapan kota tersebut adalah $40.600 \mathrm{~kg}$.

Tabel 2 Data Persediaan Plastik Bulan Mei 2015

\begin{tabular}{|c|c|c|c|c|c|}
\hline $\begin{array}{c}\text { Minggu } \\
\text { Produk }\end{array}$ & I & II & III & IV & TOTAL \\
\hline Bijih Plastik & 6000 & 6000 & 6000 & 6000 & 24.000 \\
\hline Polybag & 5000 & 5000 & 5000 & 5000 & 20000 \\
\hline
\end{tabular}

*Kuantitas produk per satuan kg

Sumber: PT.Sentosa Plastik Medan 
Tabel 3 Biaya Pendistribusian Plastik PT. Sentosa Plastik Medan per K

\begin{tabular}{|c|c|c|}
\hline Asal & Tujuan & Biaya \\
\hline \multirow{3}{*}{$\begin{array}{c}\text { Medan } \\
\text { Gudang) }\end{array}$} & Medan & 200 \\
\cline { 2 - 3 } & Aceh Tengah & 600 \\
\cline { 2 - 3 } & Duri & 625 \\
\cline { 2 - 3 } & Pekan Baru & 700 \\
\cline { 2 - 3 } & Padang & 725 \\
\cline { 2 - 3 } & Pontianak & 1650 \\
\cline { 2 - 3 } & Lampung & 1550 \\
\cline { 2 - 3 } & Jambi & 800 \\
\hline Pekan Baru & Duri & 250 \\
\cline { 2 - 3 } & Padang & 325 \\
\cline { 2 - 3 } & Pontianak & 800 \\
\hline
\end{tabular}

*Kuantitas produk per satuan kgSumber: PT.Sentosa Plastik Medan

Jika semua permintaan dipenuhi hanya dipenuhi dari kota Medan, maka total biaya yang dikeluarkan oleh PT.Sentosa Plastik Medan adalah sebesar: Rp.35.488.750;

Tabel 4 Total Biaya Pendistribusian Plastik PT. Sentosa Plastik Medan

\begin{tabular}{|c|c|c|c|}
\hline Rute & $\begin{array}{c}\text { Jumlah } \\
\text { Permintaan }\end{array}$ & $\begin{array}{c}\text { Biaya } \\
\text { Distribusi }\end{array}$ & Total \\
\hline Medan - Medan & $8150 \mathrm{~kg}$ & $\mathrm{Rp.} 200 ;$ & $\mathrm{Rp} .1 .630 .000 ;$ \\
\hline Medan - Aceh & $4700 \mathrm{~kg}$ & $\mathrm{Rp} 600 ;$ & $\mathrm{Rp} .2 .820 .000 ;$ \\
\hline Medan - Duri & $3400 \mathrm{~kg}$ & $\mathrm{Rp} .625 ;$ & $\mathrm{Rp} .2 .125 .000 ;$ \\
\hline Medan - P.Baru & $9350 \mathrm{~kg}$ & $\mathrm{Rp} .700 ;$ & $\mathrm{Rp} .6 .545 .000 ;$ \\
\hline Medan - Padang & $3450 \mathrm{~kg}$ & $\mathrm{Rp} .725 ;$ & $\mathrm{Rp} .2 .501 .250 ;$ \\
\hline Medan - Pontianak & $5950 \mathrm{~kg}$ & $\mathrm{Rp} .1650 ;$ & $\mathrm{Rp} .9 .817 .500$ \\
\hline Medan - Lampung & $3800 \mathrm{~kg}$ & $\mathrm{Rp} .1550 ;$ & $\mathrm{Rp} .5 .890 .000 ;$ \\
\hline Medan - Jambi & $5200 \mathrm{~kg}$ & $\mathrm{Rp} .800 ;$ & $\mathrm{Rp} .4 .160 .000 ;$ \\
\hline Total & $40.600 \mathrm{~kg}$ & $\mathrm{Rp} .200 ;$ & Rp.35.488.750; \\
\hline
\end{tabular}

\subsection{Pengolahan Data}


Sesuai dengan tujuan pada penulisan skripsi ini, masalah yang akan diselesaikan adalah meminimalkan biaya pendistribusian plastik agar memperoleh keuntungan yang maksimal di PT. Sentosa Plastik Medan dengan menggunakan metode transshipment. Pada permasalahan ini, kota Pekan Baru berfungsi sebagai titik transit yang juga merupakan gudang PT.Sentosa Plastik yang difungsikan untuk memenuhi permintaan yang berada disekitarnya. Hal yang harus dilakukan pertama kali adalah menyusun tabel transportasi seperti berikut:

Tabel .5 Tabel Transportasi Awal Untuk Masalah Pendistribusian Plastik

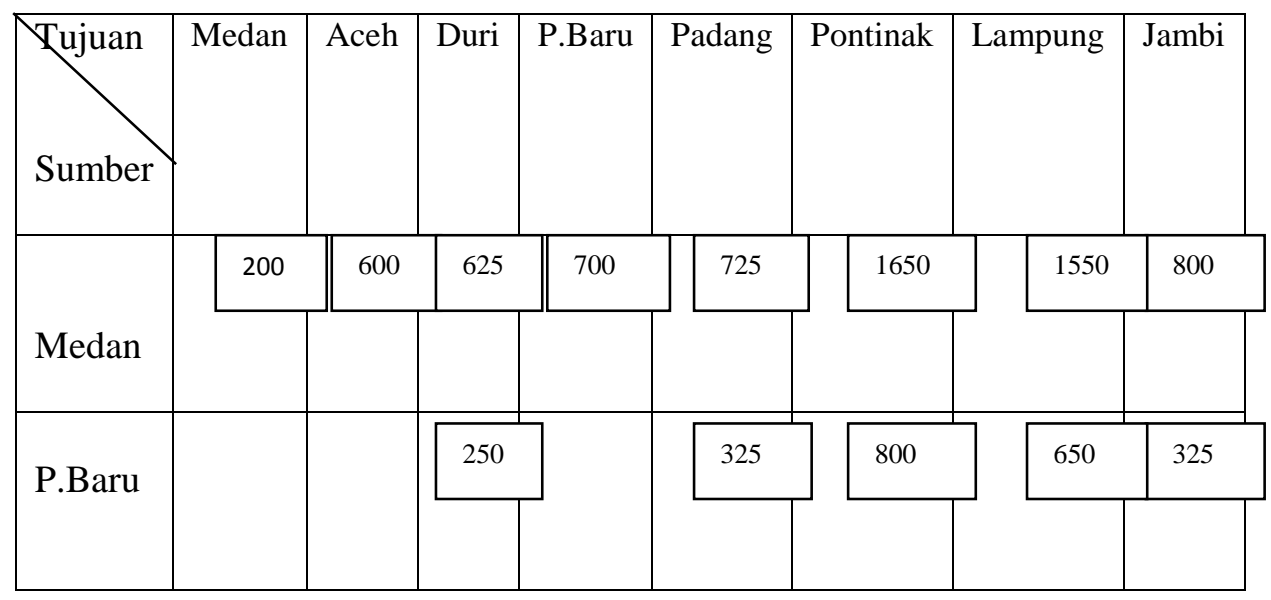

\section{Hasil dan Pembahasan}

\subsection{Solusi Awal}

\subsection{Metode Biaya Terkecil (Least Cost/LC)}

Penyelesaian masalah dengan menggunakan metode Least Cost, sesuai dengan namanya dimulai dengan memilih alokasi atau sel yang memiliki biaya pengiriman atau biaya transportasi yang paling rendah.

Tabel 6 Biaya Pengiriman atau Biaya Transportasi

\begin{tabular}{|c|c|c|c|c|c|c|c|c|c|}
\hline $\begin{array}{l}\text { Tujuan } \\
\text { Sumber }\end{array}$ & $D_{1}$ & $D_{2}$ & $D_{3}$ & $D_{4}$ & $D_{5}$ & $D_{6}$ & $D_{7}$ & $D_{8}$ & Kapasitas \\
\hline \multirow[t]{3}{*}{$O_{1}$} & & 600 & 625 & 700 & 725 & 1650 & 1550 & 800 & 24000 \\
\hline & 8150 & 4700 & & 9350 & & 1800 & & & \\
\hline & M & M & 250 & M & 325 & 800 & 650 & 325 & 20000 \\
\hline $\mathrm{O}_{2}$ & & & 3400 & & 3450 & 4150 & 3800 & 5200 & \\
\hline Kebutuhan & 8150 & 4700 & 3400 & 9350 & 3450 & 5950 & 3800 & 5200 & 44000 \\
\hline
\end{tabular}




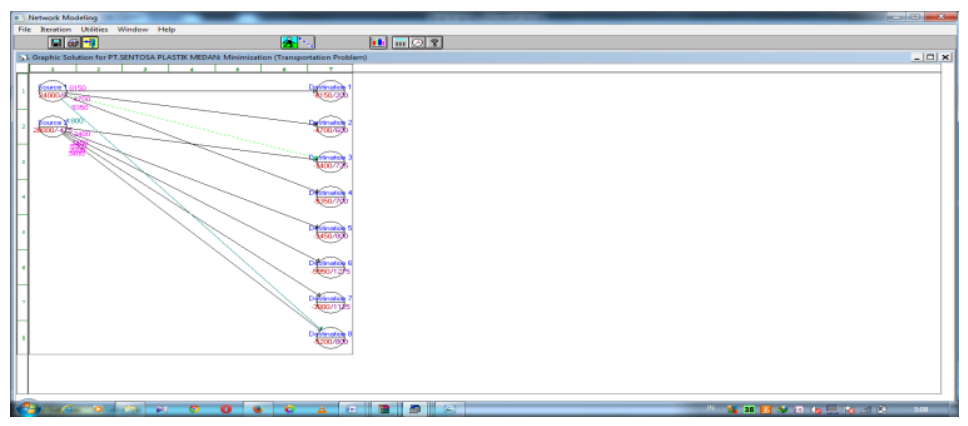

Gambar 1 Alur Distribusi Dengan Menggunakan Metode Least Cost

\subsubsection{Metode Sudut Barat Laut (North West Corner/NWC)}

Penggunaan metode NWC, sesuai namanya North West Corner akan selalu di mulai dri pojok kiri atas dari tabel transportasi.

Tabel 7 Penggunaan Metode NWC

\begin{tabular}{|c|c|c|c|c|c|c|c|c|c|}
\hline $\begin{array}{l}\text { Tujuan } \\
\text { Sumber }\end{array}$ & $D_{1}$ & $D_{2}$ & $D_{3}$ & $D_{4}$ & $D_{5}$ & $D_{6}$ & $D_{7}$ & $D_{8}$ & Kapasitas \\
\hline \multirow[t]{3}{*}{$O_{1}$} & 200 & 600 & 625 & 700 & 725 & 1650 & 1550 & 800 & 24000 \\
\hline & 8150 & 4700 & 3400 & 9350 & 2400 & & & & \\
\hline & M & M & 250 & M & 325 & 800 & 650 & 325 & 20000 \\
\hline$O_{2}$ & & & & & 1050 & 5950 & 3800 & 5200 & \\
\hline Kebutuhan & 8150 & 4700 & 3400 & 9350 & 3450 & 5950 & 3800 & 5200 & 44000 \\
\hline
\end{tabular}

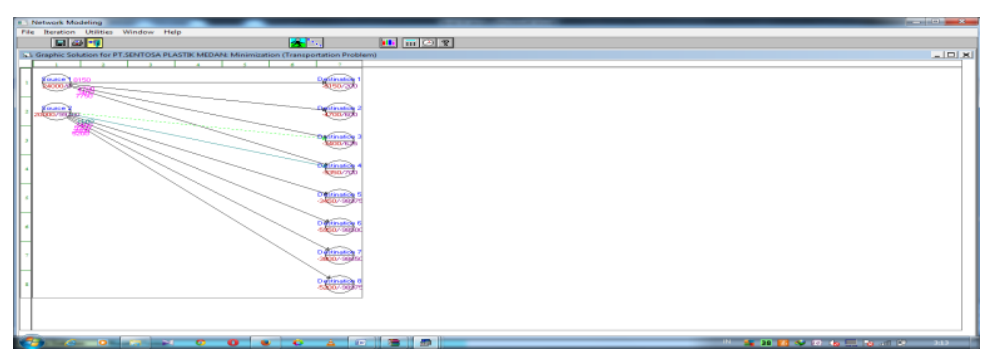

Gambar 2 Alur Distribusi Dengan Menggunakan Metode North West Corner

\subsubsection{Vogel Approximation Method (VAM)}

Dengan menggunakan Vogel Approximation Method (VAM), langkah pertama yang harus dilakukan adalah dengan cara mencari selisih antara biaya terendah pertama dan kedua dari setiap baris dan kolom pada tabel transportasinya. 
Tabel 8 Menggunakan Vogel Approximation Method

\begin{tabular}{|c|c|c|c|c|c|c|c|c|c|}
\hline Tumber & $D_{1}$ & $D_{2}$ & $D_{3}$ & $D_{4}$ & $D_{5}$ & $D_{6}$ & $D_{7}$ & $D_{8}$ & Kapasitas \\
\hline \multirow[t]{2}{*}{$O_{1}$} & 200 & 600 & 625 & 700 & 725 & 1650 & 1550 & 800 & \multirow[t]{2}{*}{24000} \\
\hline & 850 & 4700 & 1800 & 9350 & & & & & \\
\hline & M & M & 250 & M & 325 & 800 & 650 & 325 & 20000 \\
\hline $\mathrm{O}_{2}$ & & & 1600 & & 3450 & 5950 & 3.800 & 5200 & \\
\hline Kebutuhan & 8150 & 4700 & 3400 & 9350 & 3450 & 5950 & 3800 & 5200 & 44000 \\
\hline
\end{tabular}

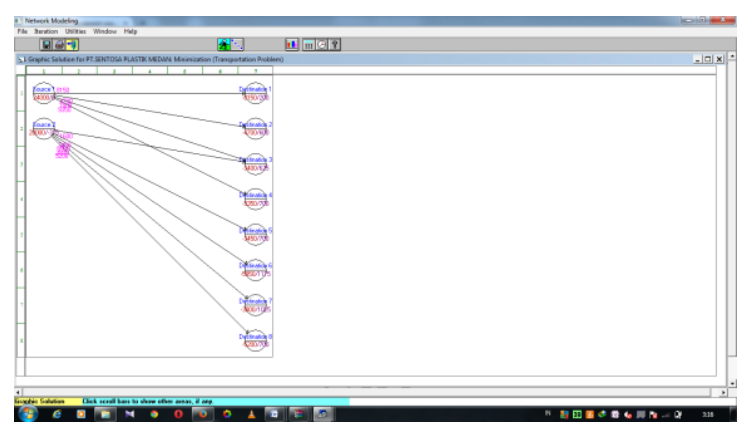

Gambar 3 Alur Distribusi Dengan Menggunakan Vogel Approximation Method

\subsubsection{Russel's Approximation Method (RAM)}

Penyelesaian kasus dengan metode ini dimulai dengan biaya tertinggi untuk setiaap baris dan kolom yang ada dalam tabel transportasinya.

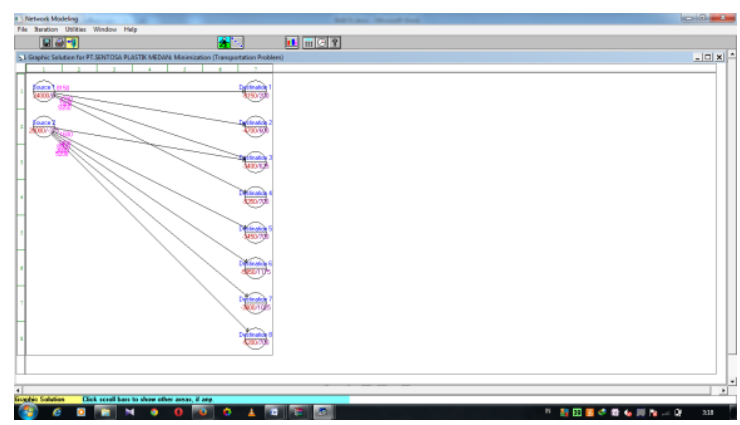

Gambar 4 Gambar Penyelesaian dengan RAM

\subsection{Solusi Optimal}

\subsubsection{Modifeid Distribution (MODI)}

Penggunaan metode MODI untuk solusi optimal, dimulai dengan mencari dan memberi nilai pada setiap baris dan kolom yang ada. Pemberian nilai pertama kali untuk baris dengan nilai nol. 
Pemberian nilai untuk yang pertama

Tabel 9 Menggunakan MODI

\begin{tabular}{|c|c|c|c|c|c|c|c|c|}
\hline Sumber & $D_{1}$ & $D_{1}$ & $D_{1}$ & $D_{1}$ & $D_{1}$ & $D_{1}$ & $D_{1}$ & $D_{1}$ \\
\hline \multirow[t]{2}{*}{$O_{1}$} & 200 & 600 & 625 & 700 & 725 & 1650 & 1550 & 800 \\
\hline & 8150 & 4700 & 3400 & 9350 & 2400 & & & \\
\hline $0_{2}$ & M & $\mathrm{M}$ & 250 & $\mathrm{M}$ & 325 & 800 & 650 & 325 \\
\hline & & & & & 1050 & 5950 & 3800 & 5200 \\
\hline
\end{tabular}

Berdasarkan pembahasan diatas, pengalokasian barang menurut kebijakan perusahaan dengan pengalokasian barang pada model transshipment yang menggunakan program $S$ Win $Q S B$ terdapat perbedaan yang cukup signifikan, serta perbedaan alokasi biaya yang berbeda. Dari kebijakan PT Senntosa Plastik Medan biaya yang diperlukan untuk mendistribusikan produk bijih plastik dan polybag sebesar 35.488.750,- sedangkan hasil analisis dengan program WinQSB di atas diperoleh biaya pendistribusian untuk seluruh produk bijih plastik dan polybag sebesar $\quad \mathbf{2 2 . 1 6 1 . 2 5 0 , -}$ Dengan menggunakan analisis di atas biaya dan proses pendistribusian barang PT Sentosa Plastik Medan akan optimal. Dari analisis di atas kita dapat mengetahui bahwa proses pendistribusian barang di PT Sentosa Plastik Medan belum optimal dari segi biaya, namun pada kenyataannya perusahaan masih mempergunakan jalur transportasi dan alokasi barang yang sudah ditetapkan pada waktu itu karena adanya pertimbangan dari faktor-faktor lain yang mempengaruhi proses pendistribusian itu sendiri, sehingga di harapkan pada masa yang akan datang kebijakan yang optimal terutama pada pendistribusian barang akan lebih tepat dan lebih baik, mengingat perusahaan akan mengembangkan pemasaran barang produksinya ke daerah Pulau Jawa.

\section{Kesimpulan}

\subsection{Kesimpulan}

Dari hasil penelitian dan pembahasan pada penelitian ini, maka simpulan yang dapat diperoleh adalah sebagai berikut.

1. Berdasarkan hasil dari model transshipment dari proses pendistribusian barang di PT. Sentosa Plastik Medan dengan menggunakan program WinQSB dihasilkan biaya pendistribusian untuk seluruh produk plastik (bijih plastik dan polybag) sebesar Rp. 24.561.250’- 
2. Perbandingan hasil model transshipment dari proses pendistribusian barang di PT. Sentosa Plastik Medan dengan model transshipment yang menggunakan program WinQSB untuk seluruh produk plastik (bijih plastik dan polybag) adalah Rp.35.488.750; berbanding Rp. 24.561.250’-

3. Penerapan model transshipment yang diterapkan di PT. Sentosa Plastik Medan belum optimal dan dapat dioptimalkan. Karena ditemukan selisih biaya pendistribusian produk platik yang berdasarkan kebijakan perusahaan dengan biaya yang dihasilkan oleh program WinQSB sebesar Rp 12.927.500,- atau 36,4\%

\subsection{Saran}

Dari hasil penelitian dan pembahasan pada penelitian ini, maka saran yang dapat diberikan adalah ketika melakukan proses pendistribusian produk dengan model transshipment perusahaan hendaknya tidak hanya memperhatikan hasil keluaran dari program WinQSB saja tapi juga memperhatikan aspek di lapangan seperti biaya bongkar muat, biaya gaji sopir, biaya gaji pembantu sopir, biaya asuransi, biaya tiap satuan pengangkutan, dan biaya penyusutan kendaraan angkutan.

\section{DAFTAR PUSTAKA}

[1] Kurniasih, Endang. 1994. Masalah Transshipment:Model Dasar dan VarisiVariasinya. Bogor: Tidak diterbitkan

[2] Hillier, Frederick S dan Lieberman, Gerald J.1990. Pengantar Riset Operasi.Bogor:PT,Gelora Aksara Pratama.

[3] Herjanto, Eddy. 1999. Perencanaan dan Pengendalian Produksi. Makridakis. Spyros.1995. Metode Dan Aplikasi Peramalan- Erlangga- Jakarta

[4] Dimyati, Tjutju T. 1994. Operation Research Model-model Pengambilan Keputusan. Bandung: Sinar Baru

[5] Aminudin.2005.Prinsip-Prinsip Riset Operasi.Jakarta:Penerbit Erlangga

[6] Gupta, Prem kumar dan Hira,D.S. 2005. Operations Research. New Delhi: S.Chand \& Company Ltd.

[7] Siswanto.2007.Operations Research. Bogor. Penerbit Gelora Aksara Pratama

[8] Nita H, Shah dan Ravi M.Gor.2008.Operations Research.New Delhi:Mudrak

[9] Wijaya,Andi.2007.Pengantar Riset Operasi. Jakarta:Mitra Wacana Media 